\begin{tabular}{ll}
\hline 薬 & 物 \\
\hline
\end{tabular}

\title{
スギ・ヒノキ花粉症患者への初期療法の検討
}

$$
\text { ーエバスチン (エバステル } \left.{ }^{\circledR}\right) \text { 投与による検討一 }
$$

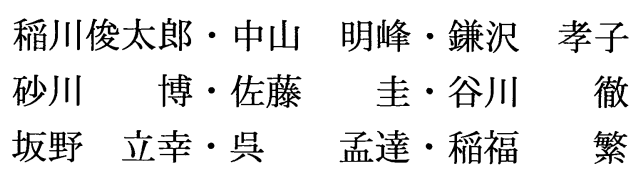

\section{The Efficacy of Prophylactic Adminstration for the Treatment of Japanease Cedar or Japanese Cypress Pollinosis}

\author{
Shuntaro Inagawa, Meiho Nakayama, Takako Kamazawa, \\ Hiroshi Sunagawa, Kei Sato, Toru Tanigawa, \\ Tatsuyuki Banno, Moutatsu Go and Sigeru Inafuku \\ (Aichi Medical University)
}

The clinical effect as well as the effect on quality of life (QOL) of ebastine were evaluated in Japanese ceder pollen allergy patients by comparing treatment before the start of pollen season and treatment after pollen had been scattered.

Seventy-seven cases could be evaluated for efficacy and safety and sixty-nine were assessed for QOL.

1) Based on the symptom score method, treatment before the pollen season showed a lower score than treatment at later time.

2) Based on the medication score method, there were no significant differences.

3) Assessment of QOL using JRQLQ showed a lower score indicating a higher QOL in patients cases treated before the start of the pollen season.

These findings suggest that prophylactic ebastine is useful for the treatment of Japanese ceder pollinosis, even when there was a small quantity of pollen.

Key words : Japanese ceder pollen allergy, ebastine, JRQLQ

はじめに

花粉をアレルゲンとしたアレルギー疾患であるスギ・ ヒノキ花粉症に対する治療として，花粉の本格飛散前か ら抗アレルギー薬を予防的に投与する「初期療法」が勃 果的とされている報告は多(1) 6). スギ花粉の飛散開始 日以前のごく少量飛散により鼻粘膜などの過敏性が立進
すると考えられており7)，初期療法はこの過敏性を抑制 し，鼻症状などの症状発現時期の遅延や，最盛飛散時期 における症状を軽減する効果が期待できる.

今回，われわれは，初期療法および飛散後投与に汎用 され, かつ脳内のヒスタミン $\mathrm{H}_{1}$ 受容体占拠率が低 ${ }^{8}$, 中枢抑制作用が少ないとされる第 2 世代の抗ヒスタミン 
薬エバスチンについて，スギ・ヒノキ花粉症患者のエバ スチン初期投与群と飛散期投与群における臨床効果およ び患者 QOL の推移を比較検討した。

\section{対象と方法}

対象は 2004 年 1 月から 4 月にかけて愛知医科大学附属 病院耳鼻咽喉科を受診した患者で，本試験の参加に同意 を得られた 16 歳以上のスギ・ヒノキ花粉症患者のうち, 下記の項目のいずれか一つを認めた患者を対象とした。

1）鼻腔所見（下鼻甲介粘膜の腫脹，下鼻甲介粘膜の色 調，水性分泌量，鼻汁の性状）のいずれかが少なくとも 陽性（+以上）の患者

2）スギまたはヒノキの CAP-RAST が陽性（クラス 1 以上）の患者

3）医師の判断でスギ・ヒノキ花粉症と診断された患者 なお，1）または3）を満たしても，スギCAP-RAST が 陰性の場合は，対象から除外することとした。

2004 年度の名古屋市におけるスギ飛散状況は, 花粉飛
散開始日が 2 月 21 日であり 7 個 $/ \mathrm{cm}^{2}$ の花粉が観察され た. 3 月 11 日には 72 個と本年最大の飛散を観察したが, 飛散終了は 3 月 27 日と例年より半月以上早いものであっ た. また, 総飛散数は 283.5 個 $/ \mathrm{cm}^{2}$ で, きわめて少量飛 散の年であった（図 1)。そこで，スギ飛散開始日以前に エバスチンの投与を開始した患者を初期投与群, 飛散開 始（2 月 21 日）以降に投与を開始した患者を飛散期投与 群とした。

方法

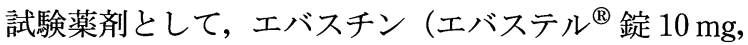
以下エバスチン）を 1 日 1 回経口投与した。 原則として 抗アレルギー薬などの併用は禁止するが，以下の薬剤は 併用可能とした。

・点鼻・点眼ステロイド薬

・点鼻点眼血管収縮薬

・点鼻点眼ケミカルメディエーター遊離抑制薬

・点鼻抗ヒスタミン薬

・経口ロイコトリエン拮抗薬

\section{固/ $\mathrm{cm}^{2} /$ 日(IS式ロータ一型)}

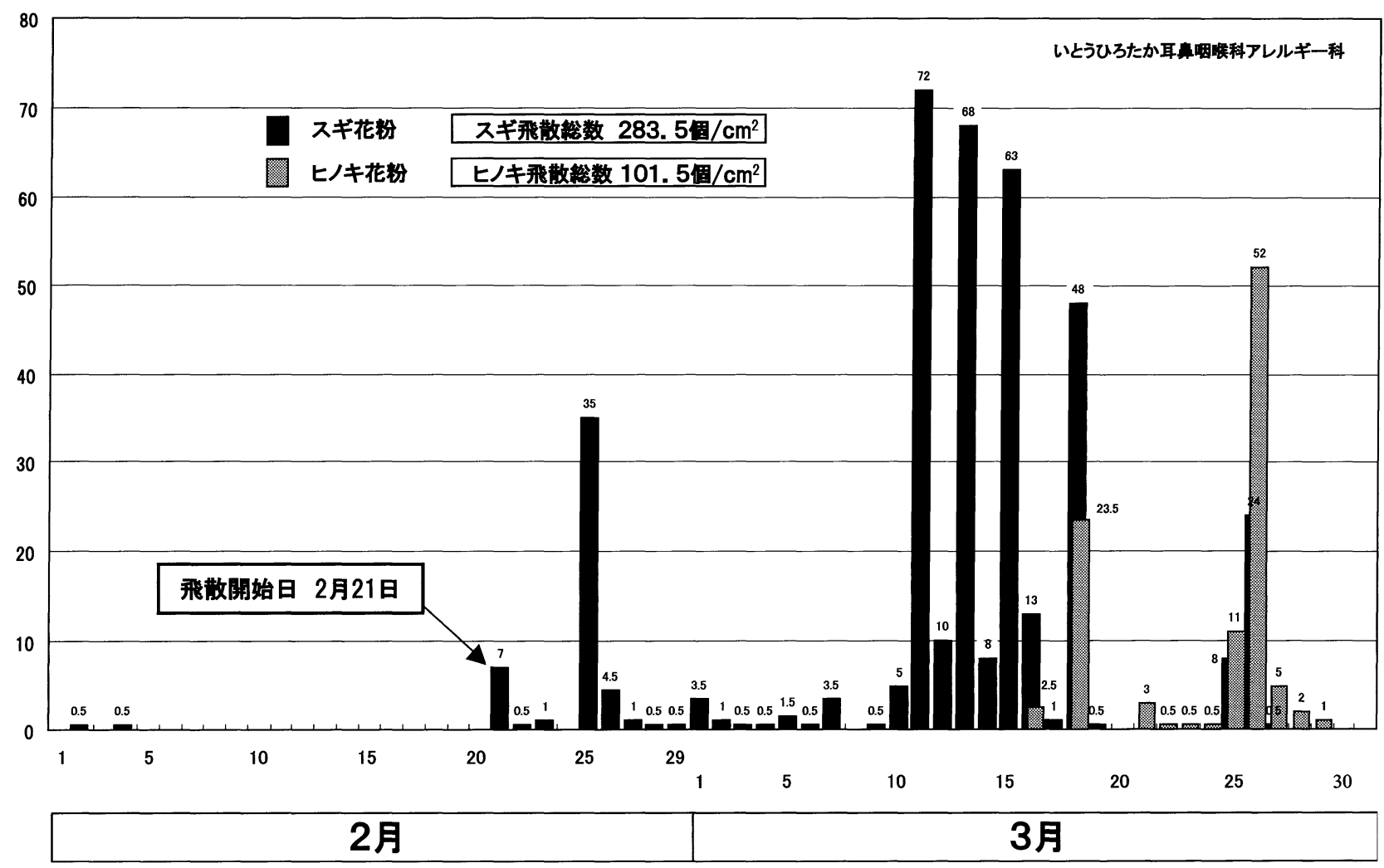

図 12004 年度のスギおよびヒノキ花粉飛散状況（名古屋市北部） 
表 1 観察期閒の区分とその期閒

\begin{tabular}{|c|c|c|c|c|}
\hline & & \multicolumn{3}{|l|}{ スギ花粉飛散開始日 } \\
\hline & - I 期 & I 期 & II 期 & III 期 \\
\hline 区分 & $\begin{array}{l}\text { 飛散開始 } 2 \text { 週前 } \\
\text { 飛散開始日前日 }\end{array}$ & $\begin{array}{c}\text { 飛散開始日 } \\
\sim \text { 飛散後 } 14 \text { 日目 }\end{array}$ & $\begin{array}{l}\text { 飛散開始後 } 15 \text { 日目 } \\
\text { ～飛散後 } 28 \text { 日目 }\end{array}$ & $\begin{array}{c}\text { 飛散開始後 } 29 \text { 日目 } \\
\text { ～飛散後 } 42 \text { 日目 }\end{array}$ \\
\hline 期間 & 2 月 $7 \underset{(2 \text { 週間 })}{2} 20$ 日 & $\begin{array}{c}2 \text { 月 } 21 \text { 日〜 } 3 \text { 月 } 5 \text { 日 } \\
(2 \text { 週間 })\end{array}$ & 3 月 $6 \underset{(2 \text { 週間 })}{\sim} 19$ 日 & $\begin{array}{c}3 \text { 月 } 20 \text { 日〜 } 4 \text { 月 } 2 \text { 日 } \\
(2 \text { 週間 })\end{array}$ \\
\hline
\end{tabular}

表 2 症状重症度スコア（symptom score）

\begin{tabular}{|c|c|c|c|c|c|c|c|c|c|}
\hline \multirow{2}{*}{\multicolumn{2}{|c|}{ 程度および重症度 }} & \multicolumn{5}{|c|}{ くしゃみ発作または鼻漏 } & & & \\
\hline & & $+H+$ & $+1+$ & +1 & + & - & & & \\
\hline \multirow{3}{*}{ 鼻 } & $\mathrm{HH}$ & 最重拄: & 最重拉: & 最更症: & 最重萑 & 最重症 & 最重拉 & $\rightarrow$ & 4 点 \\
\hline & $+1+$ & 最再婝 & 重姃 & 重症 & 重症: & 重症 & 重症 & $\rightarrow$ & 3 点 \\
\hline & ++ & 最再流 & 重症 & 中等症 & 中等症 & 中等症 & 中等症 & $\rightarrow$ & 2 点 \\
\hline \multirow[t]{2}{*}{ 閉 } & + & 最重宊 & 重应: & 中等症 & 軽症 & 軽症 & 軽症 & $\rightarrow$ & 1 点 \\
\hline & - & 最重应 & 重症 & 中等症 & 軽症 & 無症状 & 無症状 & $\rightarrow$ & 0 点 \\
\hline
\end{tabular}

表 3 薬物スコア（medication score）

\begin{tabular}{|c|c|}
\hline $\begin{array}{l}\text { 第 } 1 \text {, 第 } 2 \text { 世代抗ヒスタミン薬, } \\
\text { 遊離抑制薬 }\end{array}$ & 1 点 \\
\hline 点鼻用ステロイド薬 & 2 点 \\
\hline 点鼻用血管収縮薬, 抗コリン薬 & 1 点 \\
\hline 点眼用遊離抑制薬 & 1 点 \\
\hline $\begin{array}{l}\text { 点眼用ステロイド薬 } \\
\text { (例 : } 0.02 \% \text { フルメン }\end{array}$ & 2 点 \\
\hline 特異的免疫療法 & $\begin{array}{lr}\text { 維持量前 } & 0.5 \text { 点 } \\
\text { 維持量後 } & 1 \text { 点 }\end{array}$ \\
\hline $\begin{array}{l}\text { 経口ステロイド抗ヒスタミン薬の合剤 } \\
\text { (例 : セレスタミン) }\end{array}$ & 3 点 \\
\hline
\end{tabular}

・抗ヒスタミン薬合剤

・経口抗トロンボキサン拮抗薬

・経口 $\mathrm{Th}_{2}$ サイトカイン拮抗薬

飛散開始前の 2 週間を- I 期，その後，スギ飛散日か ら 2 週間を I 期，さらに 2 週間ごとに順次 II 期，III 期と して (表 1), くしゃみ発作, 鼻漏, 鼻閉, 日常生活支障 度を鼻アレルギー診療ガイドライン ${ }^{9)}$ に基づき，外来通 院時の問診をもとに判定した。

これらの症状のうち, くしゃみ発作, 鼻漏, 鼻閉をも とに，同じく鼻アレルギー診療ガイドラインに基づき， 各時期の重症度を評価スコア化し, 症状重症度スコア (symptom score）とした（表 2).
表 4 JRQLQ の質問項目と領域

\begin{tabular}{|c|c|}
\hline 領域 & 質問項目 \\
\hline 日常生活 & $\begin{array}{l}\text { 勉強・仕事・家事の支障（さしさわり） } \\
\text { 精神集中不良 } \\
\text { 思考力の低下（考えがまとまらない） } \\
\text { 新聞や䛃書の支障（不便） } \\
\text { 記憶力の低下（ものおぼえが悪い） }\end{array}$ \\
\hline 戸外行動 & $\begin{array}{l}\text { スポーツ, ピクニックなどの野外生活の支障 } \\
\text { 外出の支障（控えがち） }\end{array}$ \\
\hline 社会生活 & $\begin{array}{l}\text { 人とのつき合いの支障（控えがち） } \\
\text { 他人との会話・電話の支障（さしさわり） } \\
\text { まわりの人が気になる }\end{array}$ \\
\hline 睡 眠 & 睡眠障害 \\
\hline 身 体 & $\begin{array}{l}\text { 倦怠感（だるい） } \\
\text { 疹労 (つがれやすい) }\end{array}$ \\
\hline 精神生活 & $\begin{array}{l}\text { 気分が腈れない } \\
\text { いらいら感 } \\
\text { ゆううつ } \\
\text { 生活に不満 }\end{array}$ \\
\hline
\end{tabular}

さらに同時期の服用薬剤をスコア化し，薬物スコア (medication score) とした（表 3)。これらのスコアを加 算したスコアを，症状薬物スコア（symptom medication score）とした.

また,これらの問診による評価と並行して,アレルギー 性鼻炎患者の自己記入型の QOL 調查票である JRQLQ ${ }^{10)}$ 
によるアンケート調査を実施した。 JRQLQ の QOL 質問 項目 17 項目は, 日本アレルギ一性鼻炎 QOL 調查票作成 委員会の方法に準拠し,「なし (いいえ)」〜「とてもひ どい」の 5 段階で得られた回答を, それぞれ $0 \sim 4$ 点に スコア化し，6つの領域（表 4）ごとの平均点を「領域別 スコア」とした.

解析にあたっては, スコア値等の計量值については, Student's の $\mathrm{t}$ 検定を,「生活の支障度」等の順位尺度につ いては, Mann-Whitney のU 検定等を用いた.

\section{結 果}

(1) 患者背景

初期投与群 38 例, (男 : 15 例, 女 : 23 例), 飛散期投 与群 34 例（男: 12 例, 女: 22 例）の計 72 例が対象症例 となった。

両群の患者背景（年齢，性別，CAP-RAST の陽性・陰 性）には，統計学的に有意な差は認められなかった（表 5). 初期投与群の各期調查日までのエバスチンの服薬日 数は, 一 I 期 : $7.7 \pm 8.5$ 日, I 期 : 20.1 $1 \pm 9.6$ 日, II 期 : $34.4 \pm 11.6$ 日, III 期：52.8 \pm 11.2 日（平均値士標準偏 差）であった. 同様に, 飛散期投与群では, I 期 : 0 日, II 期 : $5.4 \pm 7.6$ 日, III 期 $: 14.8 \pm 11.4$ 日, であった.

（2）医師問診による評価

1）症状重症度スコア（symptom score）, 薬物スコア (medication score) および症状薬物スコア (symptom medication score) の推移

スギ花粉飛散開始前 2 週間 ( - I 期)，および飛散後 2
週間毎（I 〜 III 期）の symptom score, medication score および symptom medication score の推移を図 2 に示した. symptom score は, 一 I 期〜 III 期にわたり, 初期投与群で は飛散期投与群と比較して低い傾向で推移したが，有意 な差がみられたのはIII 期のみであった。これに対して， medication score は，期間を通じ，初期投与群と飛散期投 与群では, 大きな差はみられなかった。 また, この両者 を加算した symptom medication score は, 期間を通じ, 初 期投与群で低い值を示し， symptom score 同様，III 期に おいて有意に低いスコアを示した。

2）日常生活の支障度

一 I 期〜 III 期の「生活の支障度」の推移を図 3 に示し た. 初期投与群ではスギ飛散開始前よりも飛散後におい て,「支障なし」の患者は, 高い比率を示した。

初期投与群と飛散期投与群との比較では, いずれの期 間においても「支障なし」の患者，もしくは「支障なし 十あまり差し支えない」の患者比率は初期投与群で高く, さらに初期投与群では「手につかないほど苦しい」や「全 くできない」とする患者はみられなかった。このうち, I 期ならびに III 期の支障度は, 初期投与群で有意に低いも のであった（図 3).

（3）JRQLQよる患者 QOL の評価

72 例のうち期間中に JRQLQ アンケートに回答した 64 例について, 評価・検討を行った。 - I 期〜 III 期の JRQLQ-QOL 質問項目から得られた各領域および全 17 項 目の平均スコア推移を図 4 亿示した. 全 17 項目の平均ス コアの推移は, 初期投与群で, 飛散前〜飛散後にかけて

表 5 患者背景

\begin{tabular}{|c|c|c|c|c|}
\hline \multicolumn{2}{|c|}{ 項目 } & \multirow{2}{*}{$\begin{array}{c}\text { 初期投与群 }(\mathrm{n}=38) \\
\begin{array}{c}43.0 \pm 16.6 \text { 歳 } \\
(16 \sim 75 \text { 歳 })\end{array}\end{array}$} & \multirow{2}{*}{$\begin{array}{c}\text { 飛散期投与群 }(\mathrm{n}=34) \\
\begin{array}{c}43.3 \pm 17.2 \text { 歳 } \\
(17 \sim 77 \text { 歳 })\end{array}\end{array}$} & \multirow{2}{*}{$\begin{array}{c}\text { 検定 } \\
\mathrm{t}-\text { 検定 } \\
\mathrm{p}=0.941 \\
\mathrm{NS}\end{array}$} \\
\hline 年齢 & $\begin{array}{c}\text { 平均值士標準偏差 } \\
(\text { レンジ }\end{array}$ & & & \\
\hline \multirow{2}{*}{ 性別 } & 男 & 15 & 12 & \multirow{2}{*}{$\begin{array}{c}\chi^{2} \text { 検定 } \\
\mathrm{p}=0.715 \\
\mathrm{NS}\end{array}$} \\
\hline & 女 & 23 & 22 & \\
\hline \multirow{2}{*}{ Rast-test（スギ） } & 陽性（+） & 30 & 21 & \multirow{2}{*}{$\begin{array}{c}\chi^{2} \text { 検定 } \\
\mathrm{p}=0.109 \\
\mathrm{NS}\end{array}$} \\
\hline & 不明または実施せず & 8 & 13 & \\
\hline \multirow{3}{*}{ Rast-test（ヒノキ) } & 陽性（+） & 16 & 21 & \multirow{3}{*}{$\begin{array}{c}\chi^{2} \text { 検定 } \\
\mathrm{p}=0.101 \\
\mathrm{NS}\end{array}$} \\
\hline & 陰性（一） & 3 & 0 & \\
\hline & 不明または実施せず & 19 & 13 & \\
\hline
\end{tabular}




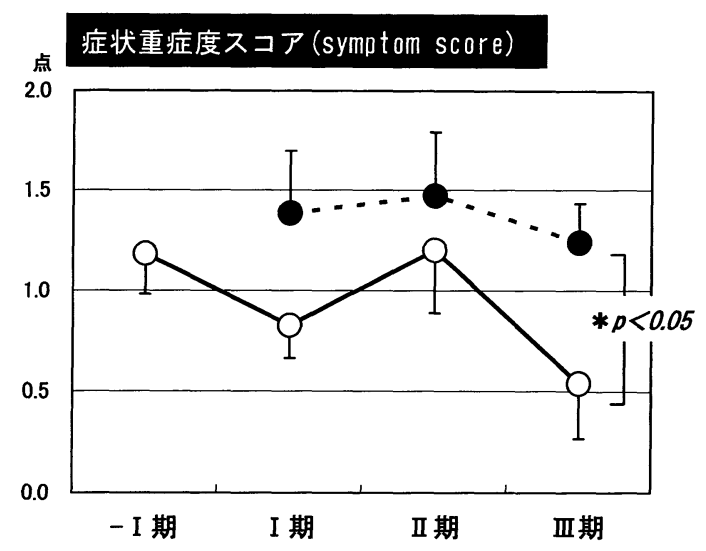

薬物スコア (medication score)

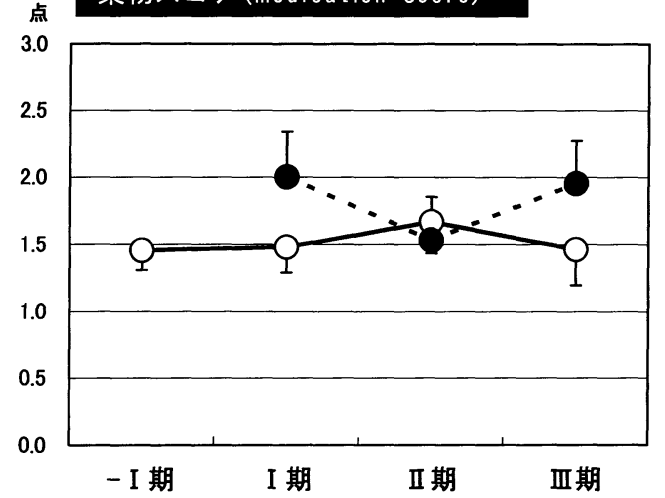

症状薬物スコア (symptom medication score)

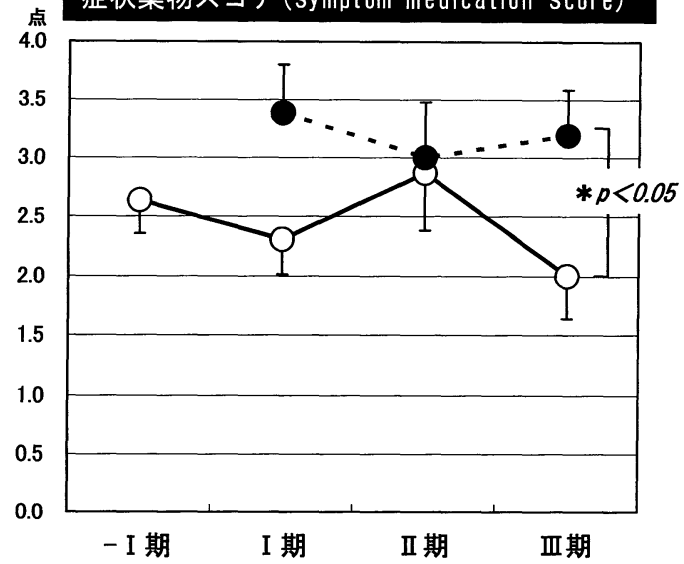

$$
\begin{aligned}
& \text { 初期投与例数 }=n 1 \\
& \text { 飛敬期投与例数 }=n 2 \\
& \text { - I 期 }: n 1=33 \\
& \text { I 期 }: n 1=23, n 2=13 \\
& \text { II 期 : } n 1=15, n 2=17 \\
& \text { III期 : } n 1=13, n 2=21
\end{aligned}
$$

Mean \pm SE

t険定(non-paired)

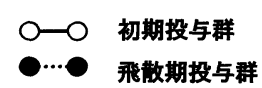

図 $2\lceil$ symptom score」「medication score」「dymptom medication score」の推移

$0.3 \sim 0.4$ と, 低い傾向があったが, 統計学的に「飛散 期投与群」との間に有意な差は認められなかった。 また, 各領域別についても同様の結果であった.

（4）安全性

全症例 72 名のうち, 初期投与群の 1 例 $(1.4 \%)$ で眠 気の副作用がみられたが, 程度は軽く継続投与可能で あった。

\section{考 察}

アレルギー性鼻炎は, 典型的な I 型アレルギーである が，気管支喘息のような致死的経過を伴わない。しかも 季節性アレルギー性鼻炎であるスギ・ヒノキ花粉症は, その有症期間は短い。しかし, 非常に強い鼻炎症状や眼 症状を示し, 日常生活上の支障度はきわめて大きい。近 年，スギ花粉症の有症率は増加の一途をたどり，1998 年 には $16.2 \%$ の有症率にいたっている.

スギ花粉症の治療法としては, 抗原除去, 特異的減感
作療法, 外科的治療, 薬物治療などがある. しかし, ス ギ・ヒノキ花粉の抗原除去には限界があり, 薬物治療が その主体となっている.これまでに，抗ヒスタミン薬の 初期治療の有用性が知られており, エバスチンにおいて も，その有用性が報告されている11122.

2003 年に「日本アレルギー性鼻炎 QOL 調查票 (JRQLQ）」10) が発表された. 今回われわれは,「鼻アレ ルギー診療ガイドライン」にもとづく, symptom score, medication score および symptom medication score 等の医 師評価とともに，この新しい JRQLQ を用いた患者記入 型の QOL アンケートを実施し, エバスチンの初期療法 の有用性を医師, 患者両方の面から検討した.

2004 年度のスギおよびヒノキ花粉の飛散量は, スギ花 粉の 1 日飛散量の最大值でも 100 個 $/ \mathrm{cm}^{2}$ 未満, 季節を通 じての飛散量も， 300 個 $/ \mathrm{cm}^{2}$ 未満であった.この結果は, 名古屋市のみならず, 大阪市, 倉敷市, 出雲市等の報 告13) でも類似したものであった。 この飛散量は, 1994 年 
ロ(-)支障なし 口(+)あまり差し支えない 图(+++)と(+)の中間 图(+++)手につかないほど苦しい ロ(++++)全くできない

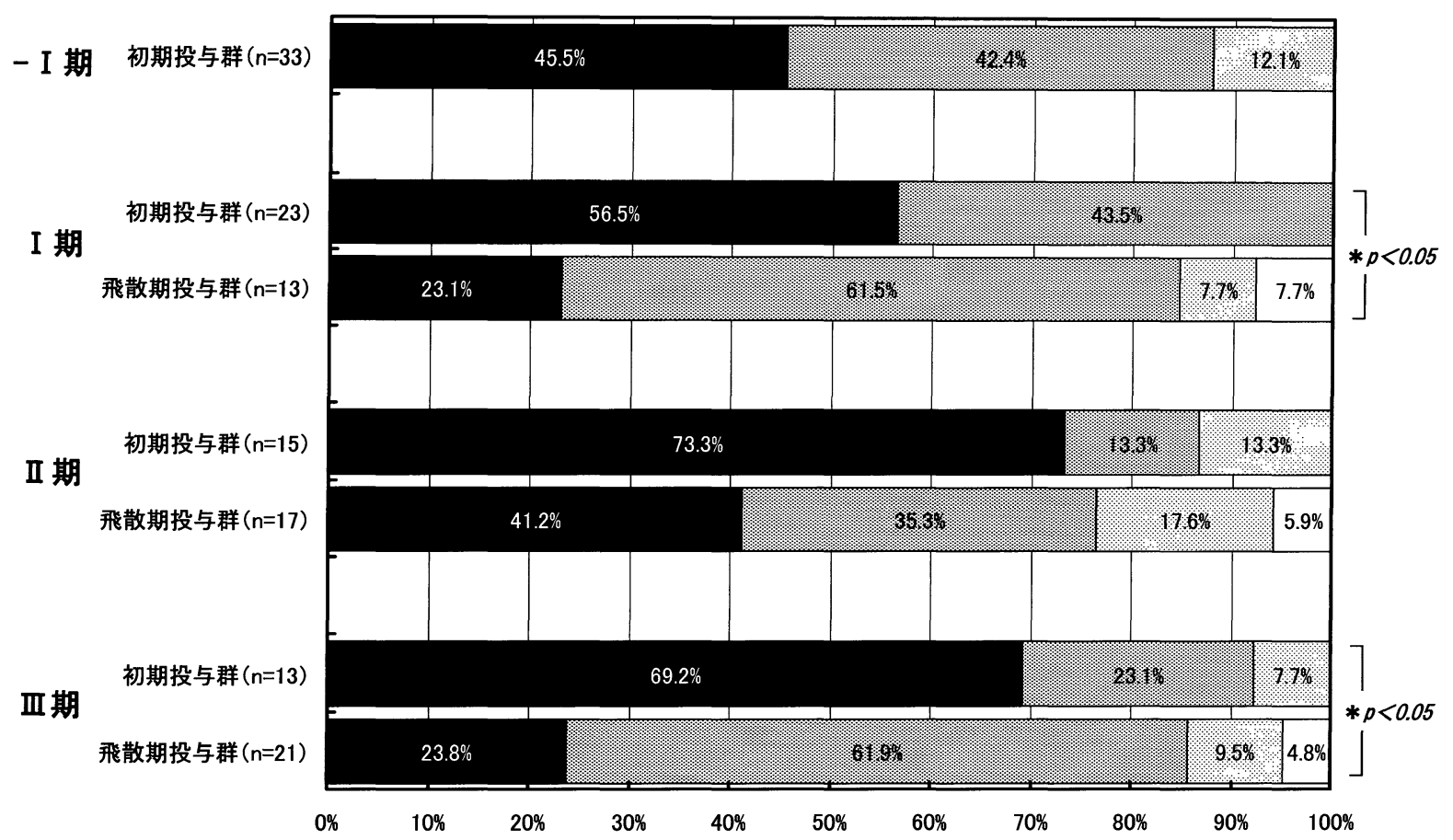

図 3 「日常生活の支障度」の推移

以来最も少ないものであった。

鈴木ら ${ }^{14)}$ は, 抗ヒスタミン薬を用いた初期療法の有用 性を，スギ花粉の飛散量が異なる 3 力年で検討している. これによると, 大量飛散時よりも, 平年並み〜少量飛散 飛散の年度での初期治療の有用性が高いことが示唆され ている.今回のわれわれの研究は，さらにスギ花粉量が 少ない年度で実施されたが, 初期治療群では 0.83-1.20 -0.54 点（それぞれ I 期，II 期，III 期）と，飛散期投与 群の 1.38-1.47-1.24 点と比べ，いずれの期間も低い symtom score で推移し, エバスチンの初期投与の有用性 が確認できた. また, medication score は, 初期投与群で は期間を通じて 1.5 程度であった。このことは，今期が 花粉飛散の少量飛散年であり，エバスチンのみの単剤治 療例が多かったことによると考えられる. 飛散期投与群 では, III 期での medication score は約 2 であり, より多 くの併用投与がなされていた. このIII 期はヒノキの飛散 ピーク時に相当し, この III 期で初期投与群は, 小さい medication score にもかかわらず，有意に低い symtom score であり,エバスチンの初期投与の有用性が確認でき た.
馬場ら ${ }^{15)}$ は，スギ花粉症状の悪化には，大量の花粉飛 散のほかに, 少量花粉の連続的曝露が関係しており, 花 粉初期における連続的な花粉抗原の刺激によって鼻粘膜 の過敏性が充進し, 同程度の花粉に曝露されても症状が 強く現れると報告している。

今回のエバスチンによる初期療法は，このような鼻粘 膜の過敏性立進を抑制することにより症状の重症化を抑 え, 結果的に飛散開始日以降の medication score を低下 させたと考えられる。

一方, symptom score においてもエバスチン初期投与 群は飛散期投与群に比べ低く推移しており，このことは 鼻閉に対する改善効果の差が大きく関与していると考え られる．鼻粘膜過敏性には, ヒスタミン以外にも好塩基 性細胞や好酸球由来のメディエーターが大きく関与して いると考えられており, エバスチンの初期投与により, それらのメディエーターの活性化が抑制された可能性も 考えられる.

JRQLQを用いた患者QOLに関しては, 全体として初期 投与群で低い傾向がみられたが，統計学的に両群に有意 な差はみられなかった。 また，各領域別についても，同 

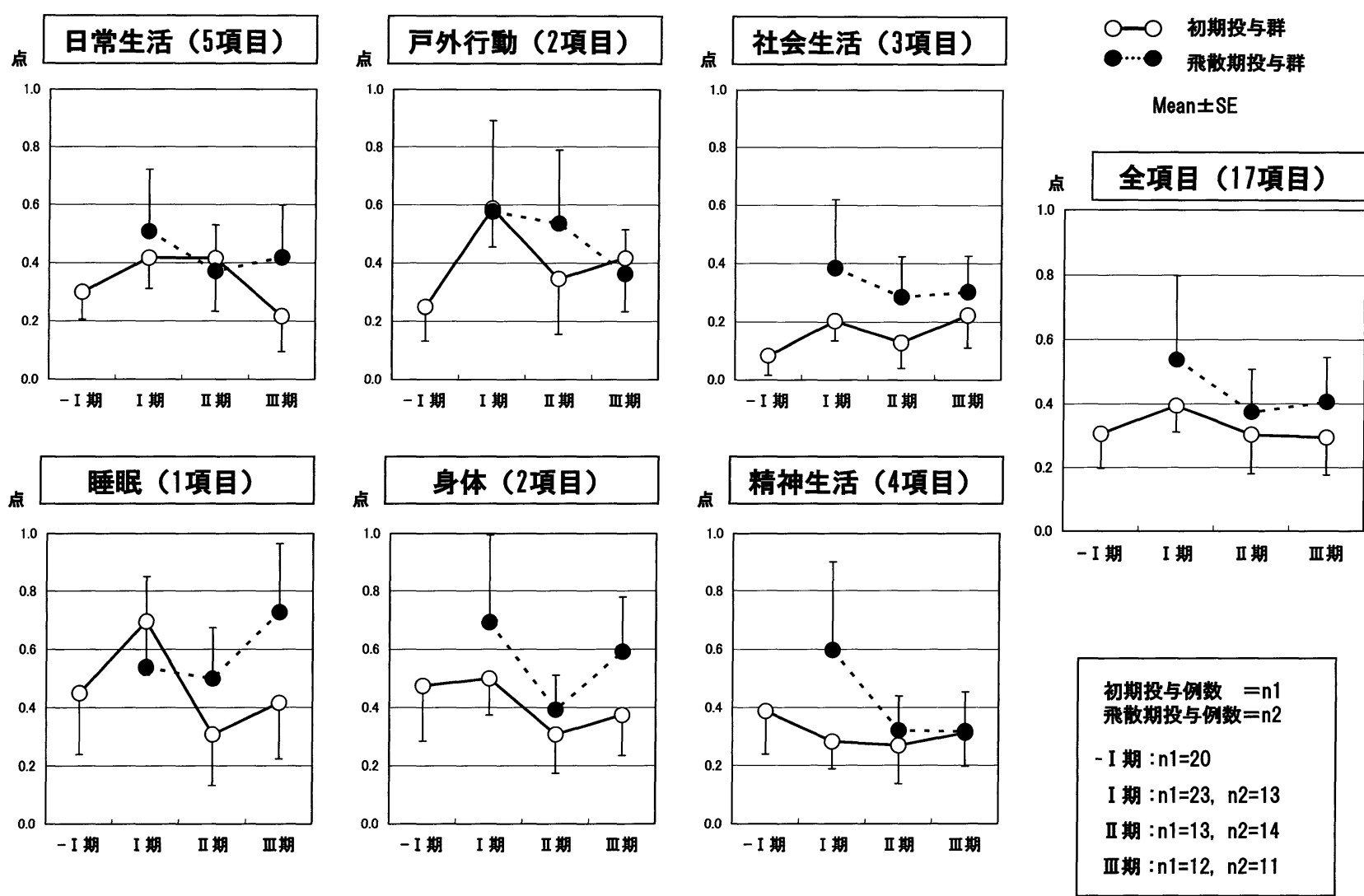

図 4 JRQLQ 患者アンケート（領域別）の推移

様の結果であった。

日本アレルギー性鼻炎 QOL 標準調查票作成委員会が 2002 年に実施した治療前後の JRQLQ スコアの検討 16) で は，治療前の総合計スコア平均は 1. 31 点（17 項目計： 22.33 点）であり，治療後は 0.73 点（17 項目計： 12.43 点）であった. これと比較して，今回われわれが得た結 果は, 全項目の平均スコアが, 初期投与群で $0.31-0.39$ -0. 30-0.29 点（それぞれ-I期，I 期，II 期，III 期）, 飛散期投与群でも $0.54-0.37-0.41$ 点（それぞれ I 期, II 期，III 期）と低い值で推移していた.

各領域別にみても, 同様の傾向がみられた. このこと は, 2002 年は平年より大量飛散がみられた年度である一 方, 2004 年はきわめて飛散少量飛散の年度であったこと によると考えられる. このように 2004 年度は，のスギ・ ヒノキ飛散による, 患者の QOL 支障度は全体的に低かっ たため, 今回の試験で初期投与群と飛散期投与群の間に 有意な差がでなかったと考えられる.

エバスチンは，1 日 1 回の服薬ですみ，脳内のヒスタ
ミン $\mathrm{H}_{1}$ 受容体占拠率が低く，中枢抑制作用が少ない抗 ヒスタミン薬とされている.この脳内のヒスタミン $\mathrm{H}_{1}$ 受 容体占拠率の低さは，エバスチンとその活性代謝物であ るカレバスチンが $\mathrm{P}$ 糖タンパクの基質となり, 脳内から 能動的に排出される17)ことが大きく関与していると考え られる.このように, 有効性のみならず服薬の簡便性, 安全性の点からも, エバスチンは, スギ・ヒノキ花粉症 患者の初期療法の第 1 選択薬の一つと考えられる.

$$
\text { まとめ }
$$

2004 年のスギ・ヒノキ花粉症患者 72 名に対し, 第 2 世代抗ヒスタミン薬エバスチンを用い, 初期投与群と飛 散期投与群における臨床効果および患者 QOL の推移を 比較検討し, 以下の成績を得た。

1）症状重症度スコア（symtom score）は，初期投与群 が飛散期投与群に比べ低い傾向を示し，III 期において統 計学的有意差を認めた.

2）薬物スコア（medication score）は，両群で有意な 
差はみられなかった。

3）JRQLQ を用いた患者 QOL は, 初期投与群が飛散期 投与群に比べ低いスコアすなわち, 高い QOL の傾向を 示した.

4）初期投与群の 1 例（1.4\%）で眠気（軽度）の副作 用がみられた。

以上の点から，エバスチンは，スギ・ヒノキ飛散少量 飛散年度に抢いて, 花粉症患者の初期療法薬剤として有 用と考えられる。

本論文の発表に際し, 名古屋市の花粉データをご提供いただ いた，いとうひろたか耳鼻咽喉科アレルギー科 伊藤博隆院長 に深謝いたします。

本論文の要旨は, 第 67 回耳鼻咽喉科臨床学会（平成 17 年 7 月 8 日，9日，松山市）に抢いてポスター発表した.

\section{参考文献}

1）奥田 稔, 古谷一郎, 佐々木好久, 他 : スギ花粉症に対す るケトチフェン季節前投与の予防効果. 耳展 29 補 $3: 277$ $\sim 293,1986$.

2）奥田 稔，矢島 洋，古谷一郎，他：スギ花粉症に対する トラニラストの季節前投与の予防効果. 耳展 30 補 $3: 219$ $\sim 243,1987$.

3）奥田 稔，斎藤洋三，石井哲夫，他：スギ花粉症に対する オキサトミドの予防・治療効果. 耳展 32 補 $4: 295 \sim 323$, 1989 .

4）井上敦子, 松永 喬, 宮原 裕, 他：スギ花粉症に対する オキサトミドの臨床効果. 耳鼻臨床 86:1203〜 1213, 1993.

5) 遠藤朝彦, 森山 寛, 山口展正, 他 : 塩酸エピナスチン (ア レジオン $\left.{ }^{\circledR}\right)$ のスギ花粉症に対する初期治療効果の臨床的 検討一飛散後投与との比較一. 耳展 $38: 800 \sim 817,1995$.

6）増田佐和子, 鵜飼幸太郎, 竹内万彦, 他：スギ花粉症への アイピーディ ${ }^{\circledR}$ 初期治療効果. 耳鼻臨床 91:639 646, 1998 。

7）馬場廣太郎 : スギ花粉症少量連続飛散による鼻粘膜過敏性,
過敏症状の変化. アレルギー科 $1: 287 \sim 298,1996$

8) Tagawa M, Kano M, Okamura N, et al. : Neuroimaging of histamine H1-receptor occupancy in human brain by positron emission tomography (PET): a comparative study of ebastine, a second-generation antihistamine, and ( + )-chlorpheniramine, a classical antihistamine. Br J Clin Pharmacol $52: 501 \sim 509$, 2001.

9）鼻アレルギー診療ガイドライン一通年性鼻炎と花粉症一 2002 年版（改訂第 4 版）ライフサイエンス（東京）.

10）奥田 稔：アレルギー性鼻炎 QOL 調查票一その開発と利用 一。アレルギー 52 補 1：1〜 11，2003.

11）荻野 敏，原田 保：スギ花粉症に対するエバスチンの効 果. 臨床医薬 $13: 5523 \sim 5533 ， 1997$.

12）石光亮太郎, 片岡真吾, 佐野啓介, 他：スギ花粉症に対す るエバスチン内服による初期治療効果の検討。臨床医薬 $13: 5535 \sim 5545,1997$.

13）竹田真理子，荻野 敏，入船盛弘，他：JRQLQ を用いたス ギ花粉症に対するエバスチン初期投与の有効性に対する検 討（第 54 回日本アレルギー学会総会 抄録）。アレルギー $53: 966,2004$.

14）鈴木直弘，稲村直樹，豊島 勝，他：スギ花粉症に対する セルテクト ${ }^{\circledR}$ (Oxatomide) の予防投与効果の臨床的検討一 オキサトミドの臨床効果一. 耳展 $38: 256 \sim 270,1995$.

15）岩瀬朗子，馬場廣太郎：春の花粉症治療の現状 a. 薬物療 法.アレルギー・免疫 $8: 187 \sim 193 ， 2001$.

16）奥田 稔，大久保公裕，岡本美孝，他：第 1 編 日本アレ ルギー性鼻炎 QOL 標準調查票（2002 年度版）。アレルギー 52 補 $1: 21 \sim 56,2003$.

17) Tamai I, Kido Y, Yamashita J, et al. : Blood-brain barrier transport of $\mathrm{H1}$-antagonist ebastine and its metabolite carebastine. J Drug Target $8: 383 \sim 393,2000$.

原稿受付：平成 17 年 7 月 13 日 原稿採択：平成17年10月14日 急載 別刷請求先：稲川俊太郎 T480-1195 愛知県愛知郡長久手町大字岩作字雁又21 愛知医科大学耳鼻咽喉科学教室 